\title{
PENGEMBANGAN MODEL PEMBELAJARAN MIND MAPPING BERBASIS TIK UNTUK MENINGKATKAN BELAJAR SENI BUDAYA
}

\author{
Syahrial Alamsyah Simatupang \\ SMK Negeri 1 Badiri Kabupaten Tapanuli Tengah, Provinsi Sumatera Utara \\ Syahrialsimatupang8@gmail.com
}

(Diterima: 12 Oktober 2020; Disetujui: 8 Desember 2020; Publikasi: 31 Desember 2020)

\begin{abstract}
ABSTRAK
Pembelajaran seni budaya menggunakan media konvensional dirasakan siswa sangat membosankan sehingga perlu dikaji inovasi model pembelajaran Mind Mapping yang berbasis TIK. Tujuannya untuk mengetahui model Mind Mapping berbasis TIK untuk meningkatkan belajar seni budaya. Penelitian menggunakan model 4D terdiri 4 tahap yaitu Define, Design, Development, dan Disseminate. Dilaksanakan di SMK Negeri 1 Badiri selama 2 bulan Tahun 2019. Populasi penelitian adalah seluruh kelas X dan sampel difokuskan kelas X OTKP dan X TKJ. Data diperoleh dari penilaian validasi ahli, angket respon peserta didik, hasil tes tertulis dan presentasi serta dokumentasi. Data dikumpulkan dan dianalisis berdasarkan validasi ahli, respon peserta didik, hasil belajar secara deskriptif kuantitatif. Analisis datanya menggunakan statistik deskriptif. Hasil penelitian ini: 1) Model pembelajaran Mind Mapping berbasis TIK dikategorikan sangat baik melalui validasi ahli; 2) Respon peserta didik pada ujicoba terbatas dan ujicoba operasional dikategorikan sangat baik; dan 3) Hasil belajar dicapai meningkat. Nilai tes tertulis kelas eksperimen lebih tinggi dari kelas kontrol sedangkan nilai tugas presentasi kelas eksperimen lebih tinggi dari kelas kontrol; 4) Efektifitas pembelajaran Mind Mapping berbasis TIK dengan sangat efektif dapat meningkat hasil belajar seni budaya.
\end{abstract}

Kata Kunci: Model Mind Mapping, TIK, Seni Budaya

\section{ABSTRACT}

Learning arts and culture that using conventional media might result in students' feeling of boredom. It is necessary to study the innovation of the ICT-based Mind Mapping learning model. The aim of this study is to find out an ICT-based Mind Mapping model to improve learning arts and culture. Research using the 4D model consists of 4 stages, namely Define, Design, Development, and Disseminate. This study was conducted at SMK Negeri 1 Badiri for 2 months in 2019. The study population was all class $X$ and the sample focused on class X OTKP and X TKJ. Data obtained from expert validation assessments, student response questionnaires, written test results and presentations and documentation. Data were collected and analyzed based on expert validation, student responses, descriptive quantitative learning outcomes. The data analysis used descriptive statistics. The results of this study: 1) 
The ICT-based Mind Mapping learning model was categorized as very good through expert validation;2) The response of students on the limited trial and the operational trial was categorized as very good, 3) Learning outcomes achieved increase. The written test score of the experimental class was higher than the control class, while the assignment value of the experimental class presentation was higher than the controlled class; and, 4) The effectiveness of ICT-based Mind Mapping learning is very effective as this increased students' learning outcomes of arts and culture.

Keywords: Mind Mapping Model; ICT; Cultural Arts

\section{PENDAHULUAN}

Pendidikan seni budaya khususnya jenjang SMK diharapkan dapat mengembangkan kemampuan peserta didik untuk mendukung kompetensi keahliannya dan menunjang mata pelajaran lain. Belajar seni budaya, peserta didik tidak dituntut harus mahir berkesenian, tetapi lebih memahami terkait kreativitas, nilai estetis, dan kegiatan berekspresi yang ditumbuh kembangkan di kelas. Proses pembelajaran di kelas mengharuskan siswa menerima dan mengolah banyak informasi. Siswa harus mencatat banyak hal penting dan di saat yang sama mereka harus mengingat informasi tersebut untuk digunakan (recall) kembali (Walida et al., 2019). Saat ini sistem pengajaran yang dirancang guru masih dilakukan secara manual dengan menggunakan media konvensional seperti media kertas, buku dan papan tulis. Kiat yang digunakan guru untuk mengatasi masalah sebaiknya dengan menerapkan strategi yang dapat membekali siswa dengan keterampilan menyimpan informasi yang diterima dalam memori jangka panjang. Kesulitan memproses dan mengorganisasi informasi ataupun materi pelajaran di sekolah dapat diatasi dengan menggunakan strategi tertentu, salah satunya adalah menggunakan Mind Mapping (Walida et al., 2019).

Mind Mapping adalah sistem berpikir yang terpancar (radiant thinking) sehingga dapat mengembangkan ide dan pemikiran ke segala arah, divergen, dan melihatnya secara utuh dalam berbagai sudut pandang (Swadarma, 2013). Metode Mind Map menjadi salah satu alternatif untuk membantu para guru dalam mengembangkan materi ajar, dapat meningkatkankan pemahaman dan kreativitas siswa dalam belajar (Karim, 2018). Tetapi pemanfaatan media pembelajaran guru saat ini dirasakan kurang menarik, sebab peserta didik merasa bosan dengan model pembelajaran konvensional tersebut. Seharusnya model pembelajaran harus ada pembaharuan dan pengembangan setiap waktu mengikuti perkembangan teknologi informasi yang berkembang. Pengembangan model pembelajaran akan meningkatkan mutu pembelajaran di Indonesia khususnya pembelajaran seni budaya yang lebih efektif dan efisien. 
Di jenjang SMK, sebagian besar peserta didik sudah memiliki peralatan teknologi komunikasi berupa laptop dan Handphone (HP). Sedangkan sekolah juga telah menyediakan laptop dan komputer dengan mengatur jadwal pemakaian. Maka, untuk pembelajaran seni budaya saat ini sangat membutuhkan peralatan TIK untuk mendukung pencarian ide atau gagasan melalui laptop atau Handphone agar memudahkan kegiatan transfer pengetahuan dan keterampilan menyajikan hasil belajar yang dibuat oleh guru dan peserta didik. Guru memiliki peranan penting untuk melakukan pengembangan pembelajaran seperti merancang model Mind Mapping berbasis TIK. Model pembelajaran ini berupaya membuka wawasan pengetahuan dan keterampilan peserta didik untuk memanfaatkan perangkat TIK dalam menelusuri materi dan menghasilkan Mind Mapping melalui aplikasi PowerPoint atau Mind Map lainnya sehingga bisa membuat dan mempresentasikankanya di depan kelas.

Berdasarkan pertimbangan terkait pembelajaran seni budaya dengan kurikulum 2013 revisi yang akan diajarkan sangat dimungkinkan diterapkannya model pembelajaran Mind Mapping berbasis TIK. Peserta didik harus menunjukkan kemampuan pikirannya dituangkan bukan lagi di kertas tapi menggunakan peralatan TIK pada aplikasi PowerPoint atau Mind Map dalam belajar seni budaya pada materi KD 3.1 dan 4.1. memahami dan mempresentasikan konsep budaya Nusantara. Permasalahan yang dikaji dalam pengembangaan model pembelajaran, lebih difokuskan pada bagaimana model pembelajaran Mind Mapping berbasis TIK dapat meningkatkan belajar seni budaya Kelas X di SMK Negeri 1 Badiri?

Pengembangan model pembelajaran Mind Mapping berbasis TIK ini bertujuan untuk mengetahui model pembelajaran Mind Mapping berbasis TIK dapat meningkatkan belajar seni budaya materi konsep budaya Nusantara. Manfaatnya bagi guru dapat dijadikan bahan rujukan menerapkan model pembelajaran seni budaya maupun pembelajaran mata pelajaran lainnya lebih lanjut dan relevan. Untuk peserta didik, model pembelajaran Mind Mapping berbasis TIK ini dapat meningkatkan hasil belajar seni budaya.

\section{KAJIAN PUSTAKA}

Model pembelajaran merupakan tahapan perencanaan yang dibuat oleh guru dalam mengatur pembelajaran secara inovatif. Model pembelajaran inovatif, progresif, dan kontekstual merupakan konsep belajar yang membantu guru mengaitkan antar materi yang diajarkan dan situasi dunia nyata siswa, dan mendorong siswa membuat hubungan antara pengetahuan yang dimilikinya dan penerapannya dalam kehiduoan mereka sebagai anggota keluarga dan masyarakat. Dengan konsep itu, hasil pembelajaran diharapkan lebih bermakna bagi siswa 
(Al-Tabany, 2017). Salah satu model pembelajaran inovatif yang sudah sering digunakan guru dalam pembelajaran dalam meningkatkan hasil belajar adalah model pembelajaran Mind Mapping.

Menurut Swadarma (2013) menyatakan bahwa Mind Mapping adalah cara mencatat yang efektif, efisien, kreatif, menarik, mudah dan berdaya guna karena dilakukan dengan cara memetakan pikiran-pikiran kita. Mind Mapping merupakan teknik visualisasi verbal ke dalam gambar. Mind Mapping sangat bermanfaat untuk memahami materi, terutama materi diberikan secara verbal. Mind Mapping bertujuan membantu anda belajar menyusun dan meyimpan sebanyak mungkin informasi yang anda inginkan dan mengelompokkannya dengan cara alami, memberi akses yang mudah dan langsung (ingatan yang sempurna) kepada apapun yang anda inginkan (Buzan, 2006).

Menurut Buzan (2007), struktur dasar Mind Mapping adalah sebagai berikut: (a) Memulai dari tengah dengan gambar Tema, menggunakan minimal 3 warna, (b) Menggunakan gambar, simbol, kode, dan dimensi di seluruh Mind Mapping yang dibuat, (c) Memilih kata kunci dan tulis dengan huruf besar atau kecil, (d) Tiap kata/gambar harus sendiri dan mempunyai garis sendiri, (e) Mengaitkan garis-garis itu, mulai dari tengah yaitu gambar tema utama. Garis bagian tengah tebal, organis, dan mengalir dari pusat keluar, menjulur seperti akar, atau pancaran cahaya, (f) Membuat garis sama panjangnya dengan gambar/kata, (g) Menggunakan warna - kode rahasia sendiri di peta pikiran yang dibuat, (h) Mengembangkan gaya penuturan, penekanan tertentu, dan penampilan khas di Peta Pikiran yang dibuat. Jadi peta pikiran setiap orang tidak harus sama, meskipun tema yang dibahas sama, (i) Menggunakan kaidah asosiasi di Mind Mapping yang dibuat dan (j) Membiarkan Mind Mapping itu jelas, menggunakan hirarki yang runtun, urutan yang jelas dengan jangkauannya.

Secara teoritis, model pembelajaran Mind Mapping berbantuan media gambar pada umumnya dapat dipahami sebagai model pembelajaran berbasis peta pikiran yang dapat membantu siswa belajar secara lebih terkonsep melalui cabang-cabang pikiran dari suatu topik dengan bantuan media gambar yang berupa foto. Dan dalam penerapannya siswa membentuk kelompok-kelompok belajar dengan kemampuan yang berbeda sehingga memungkinkan siswa saling bertukar pendapat untuk mengembangkan kemampuannya secara optimal dan berlatih untuk menemukan alternatif jawaban dari suatu konsep atau permasalahan yang dikemukakan oleh guru (Rismawati \& Ganing, 2019). Adapun langkah- 
langkah pembelajaran dalam model pembelajaran Mind Mapping, menurut Taniredja et al., (2011) adalah sebagai berikut: (1) Guru menyampaikan kompetensi yang akan dicapai, (2) Guru mengemukakan permasalahan yang akan ditanggapi peserta didik, (3) Membentuk kelompok yang anggotanya 2 sampai 3 orang, (4) Setiap kelompok menginventarisasi dan mencatat alternatif jawaban hasil diskusi, (5) Setiap kelompok secara acak atau kelompok tertentu membacakan hasil diskusinya dan guru mencatat di papan dan mengelompokkan sesuai kebutuhan, dan (6) Dari data di papan tulis, peserta didik diminta membuat kesimpulan atau guru memberikan bandingan sesuai konsep.

Pada umumnya media pembelajaran berbasis TIK banyak menggunakan peralatan komputer. Komputer adalah salah satu media yang dapat mentranformasi berbagai simbol dalam informasi dari bentuk yang satu ke bentuk lainnya. Kemampuan komputer dalam bekerja secara otomatis, terintregasi dan koordinasi dengan prosedur tetentu dan mengingat dapat dimanfaatkan sebagai suatu media pembelajaran yang baik dan efektif serta dapat difungsikan secara optimal oleh penggunanya (Akbar, 2012). Peserta didik dapat mengetik teks di komputer dengan mengubah dan mengkombinasikan ke bentuk gambar, suara, serta video. Melalui aplikasi di komputer dapat mengubah angka menjadi bentuk grafik atau kurva. Adanya guru, peserta didik, dan media diharapkan dapat menampilkan kegiatan pembelajaran menjadi menarik.

Media dalam pembelajaran memiliki fungsi sebagai alat bantu untuk menyampaikan materi yang disampaikan guru. Manfaatnya untuk menyajikan pembelajaran yang memberi pengalaman menarik dan melibatkan peserta didik berinteraksi terhadap materi. Bentuk media pembelajaran digunakan untuk model Mind Mapping berbasis TIK salah satunya adalah multimedia. Multimedia digunakan untuk menyampaikan materi yang bersifat teoritis maupun teknis bersifat klasikal. Media ini diolah di komputer melalui aplikasi dan didukung peralatan TIK seperti projector, loudspeaker, dan pointer. Melalui media ini akan menghasilkan konsep penyajian teks, video, animasi, image, grafik dan sound menjadi satu kesatuan penyajian yang menjadi bahan presentasi yang dibuat guru maupun peserta didik. Program aplikasi yang digunakan untuk merancang materi menjadi Mind Mapping yang menjadi media pembelajaran seperti aplikasi PowerPoint maupun Edwar Mind Map.

Kajian pengembangan model Mind Mapping berbasis TIK didasari dari hasil penelitian oleh Paskaria Doloksaribu (2016) dengan judul: "Pengaruh penggunaan model pembelajaran Mind Mapping berbantuan media gambar terhadap hasil belajar boga dasar 
siswa kelas X SMK Negeri 3 Pematang Siantar”. Hasil penelitian menunjukan bahwa belajar pada materi potongan sayuran pada kelas eksperimen (menggunakan model pembelajaran mind mapping berbantuan media gambar) diperoleh nilai rata- rata sebesar 77,70 dan standar deviasi 5,32 dengan tingkat kecenderungan nilai yang cukup sebesar 30\% dan tinggi sebesar 70\%. Sedangkan kelas kontrol (menggunakan model pembelajaran konvensional) diperoleh nilai rata-rata 68,59 dan standar deviasi 6,90. Dengan demikian, hipotesis yang menyatakan ada pengaruh penggunaan model pembelajaran Mind Mapping berbantuan media gambar terhadap hasil belajar boga dasar.

Pembelajaran seni budaya diupayakan dapat memberi pemahaman terkait materi yang diberikan dan peserta didik dapat mengaplikasikan dalam kehidupan sehari-hari. Melalui belajar seni budaya dalam kehidupan sehari-hari akan merangsang peserta didik untuk melestarikan budaya di daerahnya melalui konsep Mind Mapping yang mereka buat saat belajar. Penggunaan media pembelajaran dan aplikasi berbasis TIK yang efektif, efisien, dan menarik akan mempengaruhi serta meningkatkan pengalaman belajar peserta didik di masa akan datang.

\section{METODE PENELITIAN}

Salah satu hasil penelitian dan pengembangan (R \& D) adalah produk pendidikan. Produk pendidikan tidak terbatas pada produk berbentuk fisik seperti buku teks, namun bisa berupa software atau aplikasi dan model pembelajaran. Melalui pengembangan ini diharapkan produk yang telah ada menjadi semakin efektif, efisien, praktis, menarik, dan memuaskan (Sugiyono, 2015). Adapun produk pendidikan yang peneliti kembangkan adalah model pembelajaran Mind Mapping berbasis TIK dalam belajar seni budaya. Sedangkan prosedur penelitian yang digunakan adalah model penelitian yang dikemukakan oleh Thiagarajan, yang disebut Model 4D, dengan tahapan yaitu Define (pendefinisian), Design (perancangan), Development (pengembangan) dan Disseminate (penyebaran).

Tempat penelitian dilaksanakan di SMK Negeri 1 Badiri Kabupaten Tapanuli Tengah pada saat belajar seni budaya dengan durasi 3 jam pelajaran setiap minggu/kelas pada kelas $\mathrm{X}$ seluruhnya sebanyak 7 rombongan belajar dengan 6 kompetensi keahlian, diantaranya: AKL, OTKP, TKJ, NKPI, BDP dan Tata Busana. Waktu penelitian dilaksanakan selama 2 bulan, yaitu dari bulan Agustus sampai September 2019. Populasi penelitian ini adalah seluruh kelas X SMK Negeri 1 Badiri Tahun Pelajaran 2019/2020. Sedangkan sampel penelitian yakni kelas X OTKP sebagai kelas kontrol dan kelas X TKJ sebagai kelas eksperimen. Untuk uji 
coba terbatas dilakukan pada kelas X AKL sedangkan uji efektivitas dilakukan pada kelas kontrol dan kelas eksperimen. Sampel dipilih berdasarkan teknik Purposive Sample.

Teknik pengumpulan data dalam penelitian ini diantaranya: 1) Tes yaitu teknik pengumpulan data yang dilakukan untuk mengetahui peningkatan hasil belajar peserta didik terkait memahami dan mempresentasikan konsep budaya Nusantara dengan model Mind Mapping berbasis TIK. Tes ini dilakukan dengan tes tertulis dan tugas presentasi menggunakan media Mind Mapping berbasis TIK maupun berbasis konvensional, 2) Non Tes yaitu teknik pengumpulan data yang dilakukan untuk mendapatkan validasi ahli terkait kelayakan model pembelajaran Mind Mapping berbasis TIK serta angket respon peserta didik. Instrumen pengumpulan data melalui lembar kuisioner (angket) validasi ahli, lembar angket respon peserta didik, lembar tes tertulis/presentasi dan lembar observasi dan dokumentasi.

Teknik analisis data dilakukan melalui analisis validasi ahli, respon peserta didik, hasil belajar dan uji efektivitas. Model pembelajaran Mind Mapping berbasis TIK divalidasi 3 ahli yakni ahli materi, praktisi, dan media. Kemudian model diujicobakan secara terbatas pada kelas X AKL dan ujicoba operasional pada kelas kontrol X OTKP dan kelas eksperimen $\mathrm{X}$ TKJ sesuai dengan jumlah peserta didik dikelas tersebut. Setelah itu peserta didik diminta untuk mengisi angket yang telah disediakan untuk mendapatkan respon peserta didik. Langkah berikutnya dilakukan analisis data untuk rekapitulasi serta dicari skor per indikator pada lembar validasi ahli dan respon peserta didik. Penilaian masing-masing indikator diberikan skor 4 bila dinilai SB (Sangat Baik), diberikan skor 3 bila dinilai B (Baik), diberikan skor 2 bila dinilai TB (Tidak Baik) dan diberikan skor 1 bila STB (Sangat Tidak Baik), seperti tabel 1.

Tabel 1. Kategori Penilaian Indikator (Sugiyono, 2015)

\begin{tabular}{|c|c|}
\hline Kategori Penilaian & Skor \\
\hline $\begin{array}{ll}\text { SB } & \text { (Sangat Baik) }\end{array}$ & 4 \\
\hline B (Baik) & 3 \\
\hline TB (Tidak Baik) & 2 \\
\hline STB (Sangat Tidak Baik) & 1 \\
\hline
\end{tabular}

Kemudian skor diubah menjadi nilai skala 100 dengan dicari skor keseluruhan indikator nilai skala 100 sesuai dengan rumus berikut ini: 
Skor

$$
\text { Nilai }=\overbrace{\text { Skor Maksimum }} \times 100
$$

Selanjutnya, data dianalisis untuk mendapatkan uji efektivitas dengan menggunakan model penelitian eksperimen jenis Pre-Experimental Design dengan rancangan Intact-Group Comparison. Pada desain ini terdapat kelompok sebagai kelas eksperimen dan kelompok sebagai kelas kontrol (Sugiyono, 2015). Sampel tidak dipilih secara random. Adapun desain penelitian dapat dilihat seperti gambar 1.

$\mathrm{X} \quad \mathrm{O}_{1}$

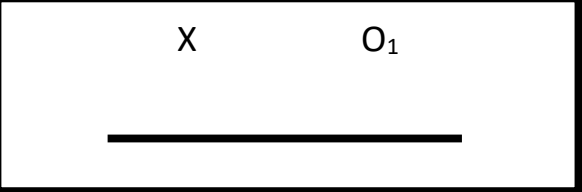

Gambar 1. Desain Penelitian (Sugiyono, 2015)

$\mathrm{O}_{1}$ adalah rerata hasil belajar kelas kontrol.

$\mathrm{O}_{2}$ adalah rerata tes hasil belajar kelas eksperimen

\section{HASIL PENELITIAN DAN PEMBAHASAN}

\section{Hasil Penelitian}

Jenis penelitian ini merupakan Research and Development (R\&D) dengan Model 4D. Model 4D memiliki tahapan diantaranya: Define (Pendefinisian), Design (Perancangan), Development (Pengembangan), dan Disseminate (Diseminasi). Penelitian dilakukan untuk menyusun dan menerapkan model pembelajaran Mind Mapping Berbasis TIK untuk meningkatkan belajar seni budaya. Melalui penelitian model 4D ini diharapkan model pembelajaran Mind Mapping berbasis TIK mendapatkan validasi ahli, respon peserta didik dan hasil belajar belajar seni budaya yang akan dijabarkan sebagai berikut.

\section{Define (Pendefinisian)}

Pada tahap Define, dilakukan kegiatan analisis melalui 6 aspek, diantaranya:

1) Analisis awal. Sebagai analisis awal dipilihnya penggunaan model Mind Mapping berbasis TIK, disebabkan kurang optimalnya media pembelajaran dalam belajar seni budaya yang masih mengacu pada buku cetak, media kertas, dan papan tulis. 
2) Analisis potensi dan kebutuhan. Di era teknologi 4.0 sudah berkembang berbagai teknologi komputer yang menerapkan aplikasi PowerPoint atau aplikasi Mind Map lainnya untuk merancang presentasi berupa Mind Mapping. Kegiatan memberi pemahaman dan presentasi materi pada peserta didik dikonsep melalui visualisasi ide-ide, gagasan dan informasi dengan menarik perhatian. Visualisasi menarik inilah digunakan untuk membuat presentasi media Mind Mapping berbasis TIK berupa kombinasi teks, gambar/foto (image), dan video/audio melaui media pembelajaran berupa HP/Laptop yang sudah tersedia di sekolah dan milik siswa.

3) Analisis silabus pada kurikulum K13 revisi diperoleh dari analisis KI (Kompetensi Inti) dan KD (Kompetensi Dasar). Penelusuran KD kajian penelitian ini difokuskan pada KD 3.1 Memahami konsep budaya Nusantara dan KD 4.1 Mempresentasikan konsep budaya Nusantara. KD 3.1 dan 4.1 tersebut dijadikan materi untuk pengembangan model Mind Mapping berbasis TIK. Media peralatan yang digunakan diantaranya: buku paket seni budaya SMK kelas X, laptop, Handphone Android, dan infocus. Aplikasi yang digunakan adalah PowerPoint dan Mind Map Edwar untuk merancang dan membuat Mind Mapping.

4) Analisis penilaian ada 2 yakni tes Tertulis dan tugas proyek/presentasi. Tes tertulis dibuat dalam bentuk tes uraian sebayak 5 soal sebagai nilai pengetahuan peserta didik pada KD 3.1. Tugas Proyek/Presentasi dibuat untuk sebagai nilai keterampilan mempresentasikan konsep budaya Nusantara khususnya budaya yang ada di Sumatera Utara pada KD 4.1. Tugas proyek/presentasi dibuat secara berkelompok dengan membuat Mind Mapping berbasis konvensional untuk kelas kontrol dan Mind Mapping berbasis TIK untuk kelas eksperimen.

5) Analisis penyusunan instrumen penelitian menggunakan lembar validasi ahli, lembar observasi keterlaksanaan RPP, dan lembar respon peserta didik, dan lembar hasil belajar.

\section{Design (Perancangan)}

Kegiatan tahap design (perancangan), ada 5 tahap yang dilaksanakan diantaranya:

1) Perumusan IPK dirancang sebagai pencapaian kompetensi pembelajaran didasarkan pada KD 3.1 dan 4.1 dengan materi memahami dan mempresentasikan konsep budaya Nusantara.

2) Pengumpulan referensi dan rancangan awal berdasarkan dari modul dan buku paket yang tersedia maupun dari penulusuran website. Berdasarkan referensi materi tersebut, maka dirancanglah desain Mind Mapping. Kelas eksperimen merancang Mind Mapping berbasis 
TIK sedangkan kelas kontrol sebagai pembandingnya membuat Mind Mapping berbasis konvensional berupa media kertas atau papan tulis.

3) Prosedur pembelajaran model Mind Mapping berbasis TIK dicapai melalui rancangan kegiatan pembelajaran meliputi: pendahuluan, kegiatan inti, dan penutup.

4) Penyusunan kelayakan instrumen dibuat untuk mendapatkan informasi terkait penerapan model Mind Mapping berbasis TIK. Penyusunan lembar validasi ahli ada 8 aspek, kelayakan Media ada 5, lembar observasi keterlaksanaan RPP ada 3 aspek, lembar respon peserta didik ada 10 pernyataan, dan lembar efektifitas ada 8 aspek. Semua lembar instrumen didesain untuk memperoleh informasi model Mind Mapping berbasis TIK.

\section{Development (Pengembangan)}

Pada tahap ini dilakukan pengembangan model Mind Mapping berbasis TIK dalam belajar seni budaya dengan materi konsep budaya Nusantara. Pengembangan dilakukan dengan 3 tahap, diantaranya: Pembuatan model Mind Mapping berbasis TIK, validasi ahli, dan ujicoba.

\section{Pembuatan Model Mind Mapping Berbasis TIK}

Banyak model Mind Mapping berbasis TIK yang telah diterapkan dalam pembelajaran. Perangkat lunak yang digunakan ada Microsoft PowerPoint dan Mind Map Edwar. Perangkat keras yang digunakan membuat, menampilkan, dan mendukung hasil Mind Mapping berbasis TIK seperti: laptop / PC, HP android, Infocus, pointer, layar screen dan speaker aktif bluetooth. Melalui Microsoft PowerPoint dan Mind Map Edwar guru dan peserta didik membuat desain Mind Mapping dengan materi konsep budaya Nusantara berupa teks, gambar, dan video/audio.

Berikut ini tampilan slide Mind Mapping yang dibuat dengan aplikasi Microsoft PowerPoint dan Mind Map Edwar yang telah dibuat dan disusun guru seperti gambar 2.
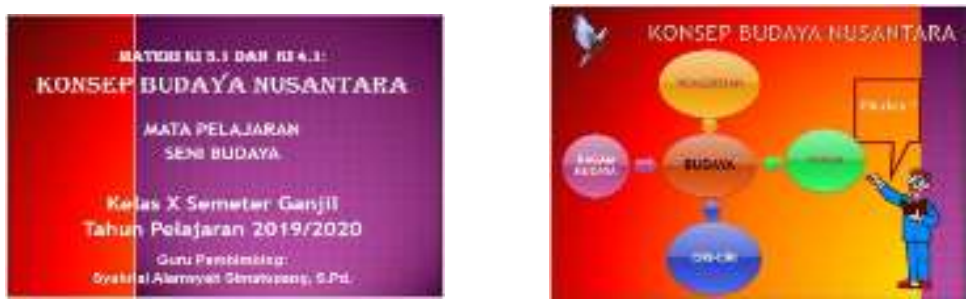

Gambar 2. Desain Mind Mapping Berbasis TIK

Penyusunan peta konsep yang baik dibuat dengan berwarna-warni menggunakan teks, gambar, simbol, maupun audio video. Kemudian Mind Mapping yang dibuat guru dan peserta didik akan dipresentasikan di depan kelas. 


\section{Validasi Ahli}

Model pembelajaran Mind Mapping berbasis TIK yang dirancang diperlukan validasi dari ahli. Validasi bertujuan untuk mengetahui kelayakan model pembelajaran Mind Mapping yang digunakan dalam ujicoba penelitian. Para ahli terdiri dari tiga orang yaitu ahli materi, teman sejawat (praktisi) dan ahli media. Berikut hasil validasi ahli tentang kelayakan model Mind Mapping berbasis TIK dijabarkan sebagai berikut: 1) Kelayakan RPP divalidasi ahli materi dengan 8 indikator penilaian diperoleh persentase 97\% kategori sangat baik. 2) Kelayakan media Mind Mapping berbasis TIK divalidasi ahli media dengan 5 indikator penilaian memperoleh persentasi 93\% kategori sangat baik., 3) Keterlaksanaan pembelajaran divalidasi ahli teman sejawat untuk mengetahui pelaksanaan model pembelajaran dengan 3 indikator yakni pendahuluan, kegiatan inti, dan penutup dengan persentasi $93 \%$ kategori sangat baik. Untuk mengetahui reliabilitas antar penilaian validator, dilakukan menggunakan Interjudge Agreement (IJA). Maka hasil analisis Percentage of Agreement model pembelajaran ini diperoleh rata-rata persentase $94 \%$ kategori sangat baik seperti terlihat tabel 2.

Tabel 2. Hasil Reliabilitas antar Validator

\begin{tabular}{clcc}
\hline No & \multicolumn{1}{c}{ Indikator Penilaian } & Penilaian Akhir (\%) & Kategori \\
\hline 1 & RPP & 97 & Sangat Baik \\
2 & Media Mind Mapping Berbasis TIK & 93 & Sangat Baik \\
3 & Keterlaksanaan Pembelajaran & 93 & Sangat Baik \\
& Rata-rata Persentase & $\mathbf{9 4}$ & Sangat Baik \\
\hline
\end{tabular}

(sumber: Data Primer yang Diolah)

\section{Ujicoba (Testing)}

Setelah divalidasi ahli model Mind Mapping berbasis TIK yang dibuat guru, langkah selanjutnya dilakukan ujicoba terbatas. Ujicoba terbatas dilakukan untuk mengetahui kehandalan model pembelajaran Mind Mapping berbasis TIK dalam belajar seni budaya materi konsep budaya Nusantara. Ujicoba terbatas dilaksanakan di kelas X AKL SMK Negeri 1 Badiri, dengan responden hadir sebanyak 33 orang. Guru menyampaikan materi konsep budaya Nusantara dengan Mind Mapping menggunakan aplikasi PowerPoint dengan peralatan TIK. Kegiatan ujicoba terbatas model pembelajaran Mind Mapping berbasis TIK dilihat seperti gambar 3.

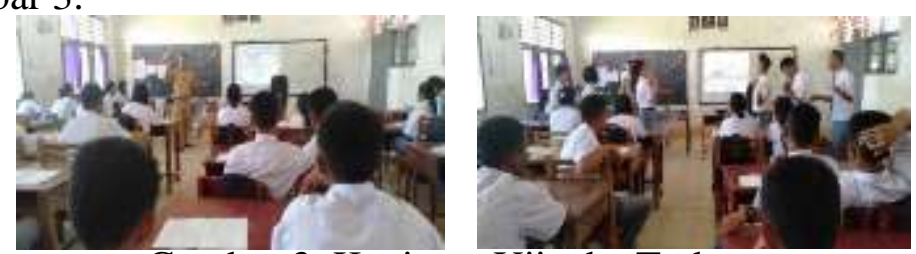

Gambar 3. Kegiatan Ujicoba Terbatas

(Sumber: Dokumentasi Penulis) 
Selesai ujicoba terbatas, peserta didik diberikan angket untuk mengetahui hasil respon peserta didik terhadap kehandalan model pembelajaran Mind Mapping berbasis TIK dengan 10 kriteria pernyataan. Berdasarkan angket respon peserta didik pada uji coba terbatas dapat dianalisis bahwa peserta didik menyatakan sangat setuju dengan respon 190 atau 58\% dan menyatakan setuju dengan respon 140 atau 42\%. Maka hasil respon peserta didik menyatakan model pembelajran Mind Mapping berbasis TIK sangat setuju diterapkan belajar seni budaya. Selanjutnya, dilakukan ujicoba operasional model pembelajaran Mind Mapping berbasis TIK dalam belajar seni budaya pada materi konsep budaya Nusantara dikelas kontrol X OTKP menggunakan media konvensional berbasis kertas sedangkan kelas eksperimen X TKJ menggunakan media berbasis TIK. Uji operasional dilakukan pada kegiatan tes tertulis dan tugas presentasi di kelas kontrol dan kelas ekperimen dapat dilihat seperti gambar 4.
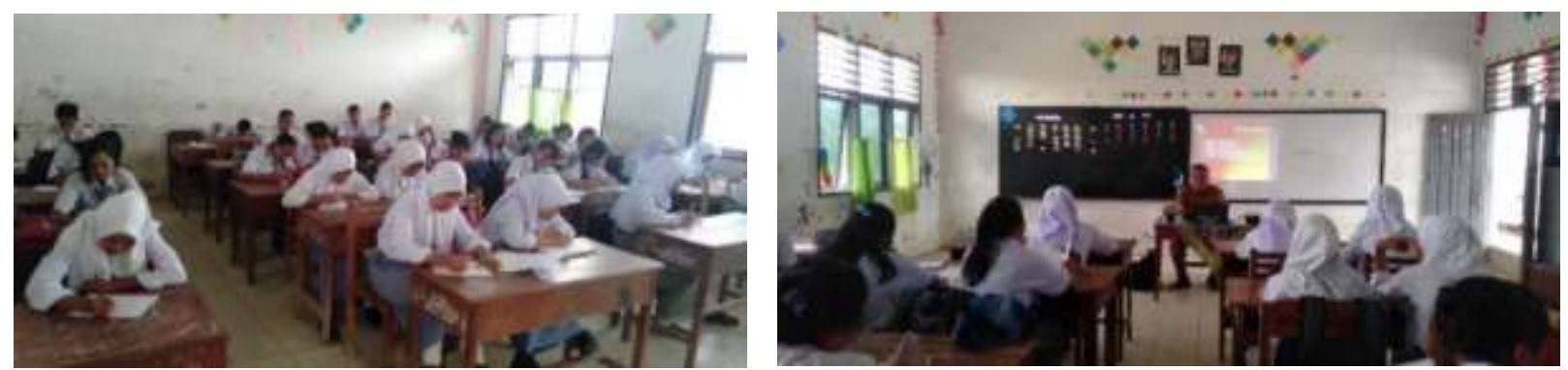

Gambar 4. Kegiatan Tes tertulis di Kelas Kontrol dan Eksperimen (Sumber: Dokumentasi Penulis)

Tes tertulis dilakukan untuk mengetahui pemahaman peserta didik terhadap konsep budaya Nusantara. Diperoleh rata-rata nilai tes tertulis di kelas kontrol adalah 80,74 sedangkan kelas eksperimen adalah 94,71. Hasil rata-rata nilai tes tertulis tersebut kelas eksperimen lebih tinggi dari kelas kontrol, dengan selisih 13,97. Sedangkan tugas presentasi di kelas kontrol dan eksperimen diberikan tugas menyusun dan mempresentasikan hasil Mind Mapping yang dibuat secara berkelompok dengan media berbasis konvensional untuk kelas kontrol dan media berbasis TIK untuk kelas eksperimen tentang konsep budaya Nusantara. Hasil Mind Mapping yang dibuat dipresentasikan secara berkelompok di depan kelas. Berikut kegiatan presentasi Mind Mapping konsep budaya Nusantara dilihat seperti gambar 5. 


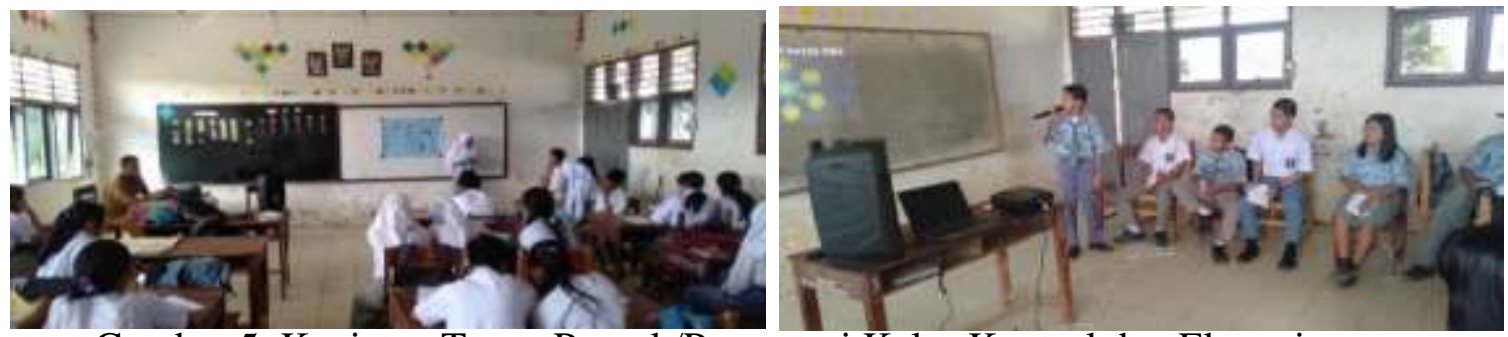

Gambar 5. Kegiatan Tugas Proyek/Presentasi Kelas Kontrol dan Eksperimen

(Sumber: Dokumentasi Penulis)

Hasil rata-rata nilai tugas proyek/presentasi sebagai nilai keterampilan di kelas kontrol adalah 79,41 dan di kelas eksperimen hasil rata-rata nilai tugas proyek/presentasi adalah 90,15. Maka, diperoleh selisih nilai rata-rata tugas proyek/presentasi sebesar 10,74. Hasil belajar seni budaya materi konsep budaya Nusantara dapat dilihat seperti tabel 3 .

Tabel 3. Rekapitulasi Hasil Belajar

\begin{tabular}{cccc}
\hline Hasil yang Dicapai & $\begin{array}{c}\text { Rata-rata } \\
\text { Kelas Kontrol }\end{array}$ & $\begin{array}{c}\text { Rata-rata Kelas } \\
\text { Eksperimen }\end{array}$ & Selisih \\
\hline Tes Tertulis (Nilai Pengetahuan) & 80,74 & 94,71 & $\mathbf{1 3 , 9 7}$ \\
Tugas Presentasi (Nilai Keterampilan) & 79,41 & 90,15 & $\mathbf{1 0 , 7 4}$ \\
\hline Rata-rata Nilai & $\mathbf{8 0 , 0 7}$ & $\mathbf{9 2 , 4 3}$ & \\
\hline
\end{tabular}

(Sumber: Data primer yang Diolah)

Diketahui juga respon peserta didik terhadap model pembelajaran Mind Mapping berbasis TIK melalui angket pada kelas eksperimen. Jumlah responden dikelas tersebut sebanyak 34 orang. Jumlah pernyataan sebanyak 8 kriteria. Berdasarkan angket respon peserta didik pada ujicoba operasional dapat dianalisis respon peserta didik yang menyatakan sangat setuju dengan respon 213 atau $78 \%$ dan menyatakan setuju dengan respon 59 atau 22\%. Maka hasil respon peserta didik menyatakan model pembelajaran Mind Mapping berbasis TIK sangat efektif meningkatkan hasil belajar seni budaya materi konsep budaya Nusantara terlihat pada tabel 4.

Tabel 4. Hasil Respon Peserta Didik

\begin{tabular}{|c|c|c|c|c|c|c|c|c|c|c|}
\hline \multirow[t]{2}{*}{ No } & \multirow[t]{2}{*}{ Kelas } & \multicolumn{2}{|c|}{ SS } & \multicolumn{2}{|c|}{$\mathbf{S}$} & \multicolumn{2}{|c|}{ TS } & \multicolumn{2}{|c|}{ STS } & \multirow{2}{*}{$\begin{array}{c}\text { Jumlah } \\
\%\end{array}$} \\
\hline & & Jml & $\%$ & Jml & $\%$ & $\%$ & $\%$ & Jml & $\%$ & \\
\hline 1 & Kontrol & 190 & 58 & 140 & 42 & 0 & 0 & 0 & 0 & 89,39 \\
\hline 2 & Eksperimen & 213 & 78 & 59 & 22 & 0 & 0 & 0 & 0 & 94,57 \\
\hline
\end{tabular}

(Sumber: Data Primer yang diolah)

\section{Disseminate (Penyebaran)}

Tahapan ini dilakukan untuk penyebaran model Mind Mapping berbasis TIK agar dapat diterapkan dalam pembelajaran seni budaya khususnya dan mata pelajaran lainnnya. Diseminasi dilakukan terhadap guru SMK Negeri 1 Badiri dan Guru Seni Budaya yang

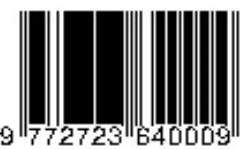


tergabung di MGMP Seni Budaya dan juga di share di akun Youtube dalam bentuk video pembelajaran.

\section{Pembahasan}

Aktivitas pembelajaran yang dirancang guru harus mengalami perubahan dan pengembangan secara terencana setiap waktu. Pengembangan belajar seni budaya khususnya SMK diharapkan dapat menumbuhkan pengalaman serta meningkatkan kemampuan peserta didik dalam memahami dan mempresentasikan budaya. Pengalaman belajar akan berlangsung baik dan menyenangkan jika ada proses interaksi belajar antara guru dan peserta didik. Setiap pembelajaran juga membutuhkan pengembangan model dan metode belajar yang efektif, efisien, dan menarik sesuai kondisi kelas yang diajar. Berbagai model dan metode pembelajaran inovatif sudah berkembang terutama model pembelajaran Mind Mapping. Untuk meningkatkan keberhasilan pembelajaran khususnya belajar seni budaya melalui materi memahami dan mempresentasikan konsep budaya Nusantara sangat efektif menggunakan model pembelajaran Mind Mapping berbasis TIK. Model ini secara langsung akan memandu peserta didik secara teori maupun praktik berinteraksi memahami dan membuat presentasi Mind Mapping berbasis TIK.

Marxy (2017) menyatakan bahwa model pembelajaran Mind Mapping merupakan model yang menggunakan peta konsep sebagai alat dalam penyampaian materi pembelajaran yang bertujuan mendorong siswa untuk belajar berpikir kritis dengan jalan memecahkan permasalahan-permasalahan. Model pembelajaran Mind Mapping dapat membantu dalam berpikir kritis. Siswa diarahkan untuk mengidentifikasi masalah, mencari alternatif pemecahan masalah, dan menemukan cara pemecahan masalah yang paling efektif, serta melakukan tindak lanjut. Pada saat mempraktikkan model pembelajaran Mind Mapping berbasis TIK, guru wajib memahami konsep pembelajaran yang telah disusun dalam RPP. Paling utama mengoperasikan media Mind Mapping untuk dipresentasikan dan diaplikasi dalam pembelajaran kepada peserta didik agar mampu membuatnya. Berikutnya, menyusun dan menetapkan langkah-langkah prosedur model pembelajaran Mind Mapping berbasis TIK agar diterapkan dengan baik. Adapun prosedur model pembelajaran Mind Mapping berbasis TIK dapat dilaksanakan, sebagai berikut: 1) Tahap persiapan: guru membuat slide Mind Mapping bersumber pada RPP, 2) Tahap proses pembalajaran: Kegiatan Pendahuluan, Inti, dan Penutup, 3) Tahap evaluasi/tindak lanjut: mengkaji dan melakukan perbaikan terhadap model pembelajaran. 
Pada saat mempraktikkan model pembelajaran Mind Mapping berbasis TIK, penulis harus memperoleh validasi dari ahli materi, media, dan teman sejawat. Mendapat respon peserta didik pada saat ujicoba terbatas dan operasional dengan kategori sangat baik. Maka sebagai guru dapat menampilkan model pembelajaran Mind Mapping berbasis TIK dan mengajak peserta didik belajar secara inteaktif melalui materi dan video pembelajaran berupa Mind Mapping yang dibuatnya sesuai konsep secara berkelompok. Hasil belajar diperoleh meningkatkan melalui tes tertulis dan tugas presentasi dikegiatan ujicoba operasional di kelas kontrol dan kelas eksperimen. Hasil tes tertulis dan tugas presentasi lebih tinggi kelas eksperimen dari pada kelas kontrol. Model Mind Mapping berbasis TIK ini dikategorikan sangat efektif dan mendukung untuk meningkatkan hasil belajar seni budaya bagi peserta didik kelas X.

Hasil penelitian yang dilakukan oleh Paskaria Doloksaribu (2016) menyatakan adanya pengaruh penggunaan model pembelajaran Mind Mapping berbantuan media gambar terhadap hasil belajar boga dasar. Begitu juga penerapan model pembelajaran Mind Mapping berbasis TIK yang penulis aplikasikan sangat menunjukkan pengaruh yang besar terhadap peningkatan belajar seni budaya. Mendapatkan hasil validasi dari ahli sangat baik dengan rata-rata persentasi $94 \%$. Mendapat respon peserta didik lebih dominan sangat setuju dari $89,39 \%$ diujicoba terbatas dan meningkat menjadi $94,57 \%$ pada ujicoba operasional. Hasil belajar meningkat melalui tes tertulis lebih tinggi kelas eksperimen dari kelas kontrol dengan selisih nilai 13,97. Sedangkan nilai tugas proyek dan presentasi lebih tinggi kelas eksperimen dari kelas kontrol dengan selisih nilai 10,74. Model pembelajaran Mind Mapping berbasis TIK mendapat respon semua pihak sehingga sangat efektif mendukung untuk meningkatkan hasil belajar seni budaya bagi peserta didik kelas X di SMK Negeri 1 Badiri.

\section{KESIMPULAN DAN SARAN}

Model pembelajaran Mind Mapping berbasis TIK telah diujikan secara terbatas dan operasional menghasilkan pembelajaran seni budaya menjadi lebih efektif, efisien, dan menarik serta menyenangkan peserta didik. Model Mind Mapping melatih peserta didik dalam menjabarkan serta mampu membuat Mind Mapping berbasis TIK terkait materi konsep budaya Nusantara, terkhusus budaya di Sumatera Utara. Berdasarkan hasil penelitian dan pembahasan, dapat disimpulkan sebagai berikut: 1) Model pembelajaran Mind Mapping berbasis TIK yang dirancang guru memperoleh validasi ahli dengan kategori sangat baik dan layak diterapkan dalam belajar seni budaya, 2) Respon peserta didik pada ujicoba terbatas dan ujicoba operasional sangat setuju model pembelajaran Mind Mapping berbasis TIK 
diterapkan dalam belajar seni budaya, 3) Hasil belajar diperoleh melalui tes tertulis dan tugas proyek/presentasi mengalami peningkatan dengan hasil lebih tinggi rata-rata nilai kelas eksperimen dari pada rata-rata nilai kelas kontrol. 4) Model pembelajaran Mind Mapping berbasis TIK juga dikategorikan sangat efektif untuk meningkatkan hasil belajar seni budaya materi konsep budaya Nusantara.

Saran yang bisa diberikan sebagai berikut: 1) Model pembelajarn Mind Mapping berbasis TIK sangat efektif, efisien, dan menarik, maka ketika guru menggunakan model pembelajaran ini harus sesuai tersedia peralatan TIK. 2) Media Mind Mapping berbasis TIK menggunakan aplikasi PowerPoint atau aplikasi Mind Map lainnya dapat dikembangkan dengan kombinasi aplikasi lainnya. 3) Hendaknya dapat berinovasi mengembangkan model Mind Mapping agar berkembang inovasi pembelajaran seni budaya. 4) Melakukan evaluasi setiap waktu terkait motivasi belajar peserta didik dalam menggunakan Mind Mapping berbasis TIK pada materi lainnya. 5) Melakukan penyebarluasan model pembelajaran Mind Mapping berbasis TIK yang disampaikan pada guru seni budaya kelas X jenjang SMK atau di-share pada website, Youtube, atau surel, WA atau FB group agar dapat dimanfaatkan sebagai rujukan bagi guru seni budaya.

\section{DAFTAR PUSTAKA}

Akbar, S. A. (2012). Pemanfaatan Media Pembelajaran Berbasis Komputer pada Mata Pelajaran Seni Budaya Semester Ganjil Kelas X SMK Muhammadiyah 2 Kediri Tahun 2011/2012. Universitas Negeri Malang.

Al-Tabany, T. I. B. (2017). Mendesain Model Pembelajaran Inovatif, Progresif, dan Konteksual. Prenada Media.

Buzan, T. (2006). Buku Pintar Mind Map. Gramedia Pustaka Utama.

Buzan, T. (2007). Buku Pintar Mind Map untuk Anak: agar Anak jadi Pintar di Sekolah. Gramedia Pustaka Utama.

Doloksaribu, P. (2016). Pengaruh Penggunaan Model Pembelajaran Mind Mapping Berbantuan Media Gambar Terhadap Hasil Belajar Boga Dasar Siswa Kelas X SMK Negeri 3 Pematangsiantar. UNIMED.

Karim, A. (2018). Efektivitas Penggunaan Metode Mind Map pada Pelatihan Pengembangan Penguasaan Materi Pembelajaran. IJTIMAIYA, 1(1).

Marxy, A. (2017). Pengaruh Model Pembelajaran Mind Mapping terhadap Hasil Belajar Matematika Siswa. JKPM (Jurnal Kajian Pendidikan Matematika), 2(2), 173-182. 
Rismawati, N. W. R., \& Ganing, N. N. (2019). Pengaruh Model Pembelajaran Mind Mapping Berbantuan Media Audiovisual Terhadap Kompetensi Pengetahuan Ipa. Journal for Lesson and Learning Studies, 2 (3), 351-360.

Sugiyono, M. (2015). Penelitian \& Pengembangan (Research and Development/R\&D). Bandung: Penerbit Alfabeta.

Swadarma, D. (2013). Penerapan Mind Mapping dalam Kurikulum Pembelajaran. Jakarta: PT. Alex Media Komputindo

Taniredja, T., Faridli, E. M., \& Harmianto, S. (2011). Model-Model Pembelajaran Inovatif. Alfabeta.

Walida, L. F. A. R., Agustini, R., \& Tukiran, T. (2019). Pengembangan Perangkat Pembelajaran Model Inkuiri Terbimbing Mind Mapping untuk Meningkatkan Hasil Belajar Siswa pada Materi Hidrolisis Garam. Journal of Science Education and Practice, 1(1), 59-66. 